Provided for non-commercial research and education use. Not for reproduction, distribution or commercial use.

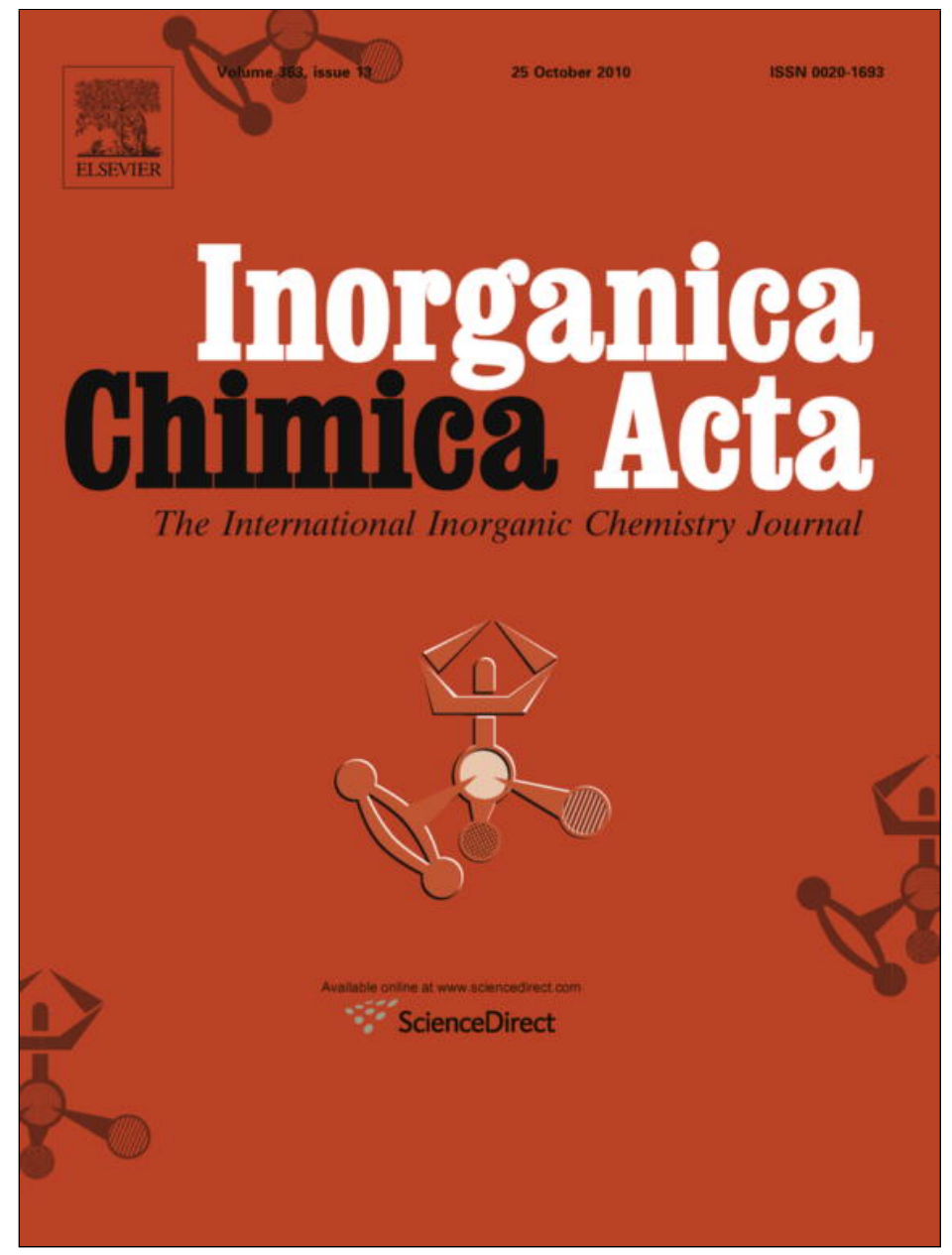

This article appeared in a journal published by Elsevier. The attached copy is furnished to the author for internal non-commercial research and education use, including for instruction at the authors institution and sharing with colleagues.

Other uses, including reproduction and distribution, or selling or licensing copies, or posting to personal, institutional or third party websites are prohibited.

In most cases authors are permitted to post their version of the article (e.g. in Word or Tex form) to their personal website or institutional repository. Authors requiring further information regarding Elsevier's archiving and manuscript policies are encouraged to visit:

http://www.elsevier.com/copyright 


\title{
A study on the insertion of isocyanides into palladium allyl bond: Effect of their nature on the strategic steps of the process
}

\author{
Luciano Canovese, Gavino Chessa, Fabiano Visentin * \\ Dipartimento di Chimica, Università Ca' Foscari Venezia, Calle Larga S. Marta 2137, 30123 Venice, Italy
}

\section{A R T I C L E I N F O}

\section{Article history:}

Received 30 March 2010

Received in revised form 22 June 2010

Accepted 28 June 2010

Available online 8 August 2010

\section{Keywords:}

Isocyanide insertion

Palladium allyl complexes

Mechanistic study

\begin{abstract}
A B S T R A C T
The coordinative capabilities of tert-butyl isocyanide (TIC) and 2,6-dimethylphenyl isocyanide (DIC) were shown to be perfectly comparable in spite of their different steric and electronic features. As a matter of fact, when equimolar amounts of these two isocyanides are made to compete for the same coordination sites of a Pd-allyl substrate the statistical mixture of the possible products is always observed.

On the contrary, the DIC proved to be much more efficient than TIC in promoting the migratory insertion of an allyl fragment. This conclusion was simply based on the analysis of the products resulting from the reaction of an appropriate Pd-allyl complex with both isocyanides simultaneously.
\end{abstract}

(c) 2010 Elsevier B.V. All rights reserved.

\section{Introduction}

The insertion of unsaturated molecules into carbon-palladium bonds represents a fundamental step in many catalytic processes [1]. In this context isocyanide (CNR) insertion into $\mathrm{Pd}-\mathrm{C}$ bonds has been extensively studied [2]. Isocyanides are a class of unsaturated carbon ligands isoelectronic with carbon monoxide but potentially more versatile since their electronic and steric properties can be widely varied depending on the nature of the substituent $\mathrm{R}$. The insertion ability of isocyanides differs in part from that of carbon monoxide. In particular, consecutive CO insertions are disfavoured while isocyanides easily undergo the consecutive multiple process [3]. This behaviour, albeit leading to new types of organic compounds difficult to synthesize by other methods, renders the mechanistic investigations of the system very difficult. Also for this reason the kinetic studies reported in the literature are not so numerous, and the most exhaustive results were obtained when it was possible to limit the process to monoinsertion. To attain this aim the choice of the spectator ligands is of fundamental importance: aryl- or methyl-palladium complexes with nitrogen bidentate ligands [4] and with mixed phosphorus-nitrogen or sulphur-nitrogen ligands [5] give monoinserted iminoacyl derivatives in the presence of a stoichiometric amount of isocyanide whereas under the same conditions the exclusive use of phosphines as ancillary ligands often induces the polyinsertion [6].

Recently we have proposed a detailed study of the monoinsertion of isocyanides into Pd-allyl complexes [7]. According to this mechanism, the neutral species $(\mathbf{I})$, bearing the $\eta^{1}$-allyl fragment

\footnotetext{
* Corresponding author.

E-mail address: fvise@unive.it (F. Visentin).
}

in trans position to the chloride, represents the crucial intermediate for the formation of the final imino-3-butenyl product (see Scheme 1). For this reason it becomes of remarkable importance to asses the coordinating capability of the employed isocyanide since it determines the concentration of the "active" species (I). At the same time it is fundamental to establish the efficiency of isocyanide in promoting the subsequent insertion, which represents the rate-determining step of the process.

The main goal of this report is to prove that the electronic and steric features of the isocyanide influence the rate-determining insertion step much more than pre-coordination to the metal centre.

\section{Results and discussion}

The strategy adopted to attain our aim is based on the direct comparison between two different isocyanides which are made to compete for the same palladium substrate in solution. In this connection we chose the tert-butyl isocyanide (TIC) and the 2,6dimethylphenyl isocyanide (DIC) as representative compounds. These two species are sufficiently different, the former being much more electron-donating and more sterically encumbered than the latter. This significant difference should magnify the effect of the nature of the isocyanide substituent on its coordinating ability and on its capacity of promoting migratory insertion of the allyl group.

\subsection{Coordination efficiency}

A simple experiment allowed us to compare the coordination efficiency of the two isocyanides. It consists in adding equimolar 

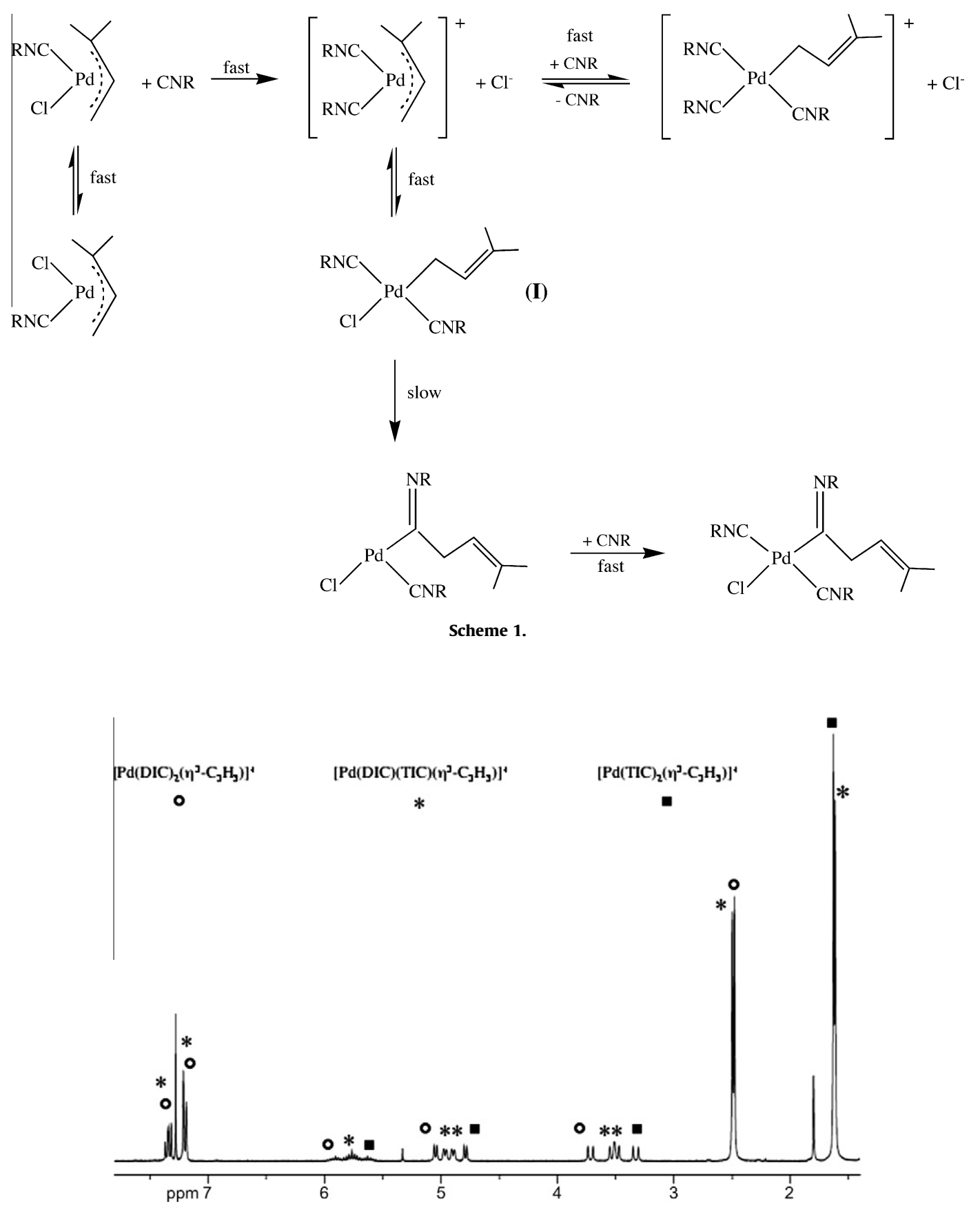

Fig. 1. ${ }^{1} \mathrm{H}$ NMR spectrum (in $\mathrm{CDCl}_{3}$ at $253 \mathrm{~K}$ ) related to the products of the reaction of $\left[\mathrm{Pd}(\mu-\mathrm{Cl})\left(\eta^{3} \text {-allyl) }\right]_{2}\right.$ with 2 equiv. of DIC and 2 equiv. of TIC in the presence of an excess of $\mathrm{NaClO}_{4}$.

amounts of DIC and TIC to the [Pd ( $\eta^{3}$-allyl)] fragment. This can be experimentally obtained by adding 2 equiv. of DIC and two equivalents of TIC to a solution of the dimer $\left[\mathrm{Pd}(\mu-\mathrm{Cl})\left(\eta^{3}-\mathrm{C}_{3} \mathrm{H}_{5}\right)\right]_{2}$, dissolved in a 3:1 mixture of $\mathrm{CH}_{2} \mathrm{Cl}_{2}: \mathrm{CH}_{3} \mathrm{OH}$, in the presence of an excess of $\mathrm{NaClO}_{4}$ [8]. These conditions allow the complete removal of chloride which otherwise would compete for the coordination sites and basically start up the process of isocyanide insertion [7].

The ${ }^{1} \mathrm{H}$ NMR spectrum of the products obtained by this procedure is reported in Fig. 1.

The result is clear and noteworthy since a statistical mixture of the three possible products was practically obtained. The signals of the two homoleptic complexes $\left[\mathrm{Pd}(\mathrm{DIC})_{2}\left(\eta^{3}-\mathrm{C}_{3} \mathrm{H}_{5}\right)\right]^{+}(\sim 25 \%)$ and $\left[\operatorname{Pd}(\mathrm{TIC})_{2}\left(\eta^{3}-\mathrm{C}_{3} \mathrm{H}_{5}\right)\right]^{+}(\sim 25 \%)$ are located in the spectrum by comparison with the spectra of authentic samples independently syn- thesized. The residual signals are consistent with those of the mixed species $\left[\mathrm{Pd}(\mathrm{DIC})(\mathrm{TIC})\left(\eta^{3}-\mathrm{C}_{3} \mathrm{H}_{5}\right)\right]^{+}(\sim 50 \%)$.

The significance of this response is that DIC and TIC exhibit essentially the same coordinating ability toward the palladium(II) substrate.

\subsection{Insertion efficiency}

As pointed out in Scheme 1 the presence of chloride is a necessary condition to promote the insertion of isocyanides into the Pdallyl bond [7]. Moreover, the intermediate I represents the species in which migration of the allyl group effectively occurs. The $\eta^{1}$-allyl fragment can potentially move toward both the coordinate isocyanides in cis position, but if they are different one of the two sites 
<smiles>CC(C)=CCC(=Nc1c(C)cccc1C)[R](Cl)([Ge])C(=O)c1ccccc1</smiles>

1

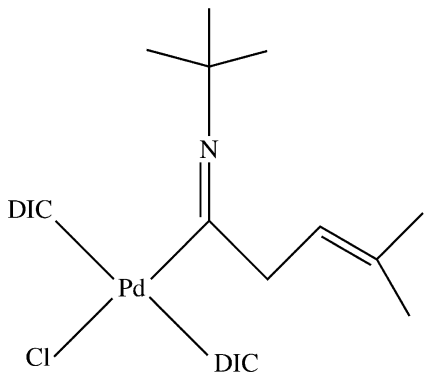

4<smiles>CC[Te](Cl)(Br)C(CC=C(C)C)=Nc1c(C)cccc1C</smiles>

2<smiles>CC(C)=CCC(=NC(C)(C)C)[R]([Al])(Cl)[Ba]</smiles>

5<smiles>CC(C)=CCC(=Nc1c(C)cccc1C)[Ge](Cl)(Cl)Cl</smiles>

3<smiles>CC(C)=CCC(=NC(C)(C)C)[R]([Al])([Al])Cl</smiles>

Chart 1.

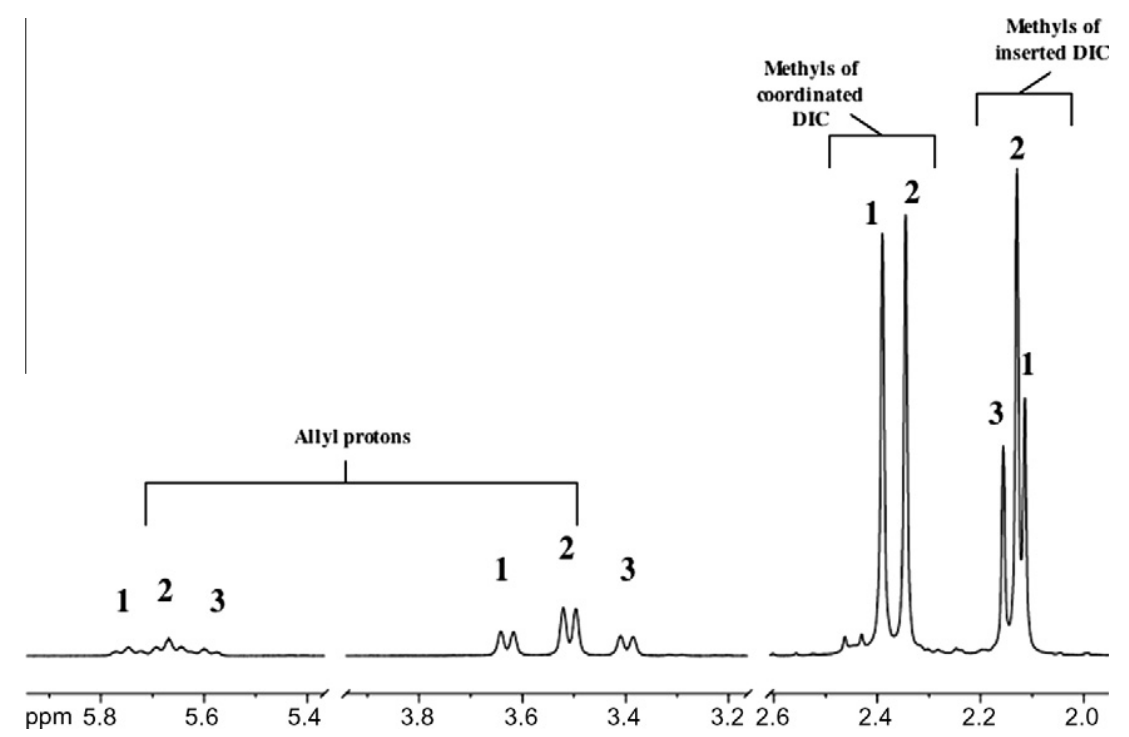

Fig. 2. Extract of ${ }^{1} \mathrm{H}$ NMR spectrum (in $\mathrm{CDCl}_{3}$ at $298 \mathrm{~K}$ ) related to the reaction of [Pd(DIC)Cl$\left.\left(\eta^{3}-\mathrm{C}_{3} \mathrm{H}_{3} \mathrm{Me}_{2}\right)\right]$ with 1 equiv. of DIC and 1 equiv. of TIC.

might become preferable. With this assumption, an accurate analysis of the product mixture obtained by the reaction of an appropriate allyl palladium substrate with DIC and TIC in the presence of chloride may be a useful tool to evaluate the insertion capability of the two isocyanides. An experimental option to realize this study consists in the addition of one equivalent of TIC and one of DIC to a $\mathrm{CDCl}_{3}$ solution of the neutral complex $\left[\mathrm{Pd}(\mathrm{DIC}) \mathrm{Cl}\left(\eta^{3}-\right.\right.$ $\left.\left.\mathrm{C}_{3} \mathrm{H}_{3} \mathrm{Me}_{2}\right)\right]$. The choice of a dimethyl derivative simplifies the interpretation of the final spectrum, whereas the 3:1 ratio between palladium and the overall isocyanide species ensures the complete conversion of the allylic reagent into the insertion products. The six possible final complexes are represented in Chart 1.
However, as results from the analysis of the ${ }^{1} \mathrm{H}$ NMR spectrum ${ }^{1}$ recorded after the mixing of the reagents (Fig. 2), the only observa-

${ }^{1}$ For the identification of the compounds present in the final mixture it is especially profitable to consider the different positions of the signals relative to the coordinate and to the inserted DIC in the ${ }^{1} \mathrm{H}$ NMR spectrum. In particular the methyl signals of the inserted DIC (one singlet for every species) lie to higher field than those of the coordinated DIC (one singlet for every species). Thus it is possible to establish the number of the species with inserted DIC $(\mathbf{1}, \mathbf{2}, \mathbf{3})$ and then, by integration of the signals (and in some case by ${ }^{1} \mathrm{H}-{ }^{1} \mathrm{H}$ COSY inter-peaks) to determinate the signals of the coordinated DIC (if existing) and of the allyl protons of each species. Moreover it is important to remind that the spectra of species $\mathbf{1}$ and $\mathbf{6}$ are already known (see Refs. [6]). 


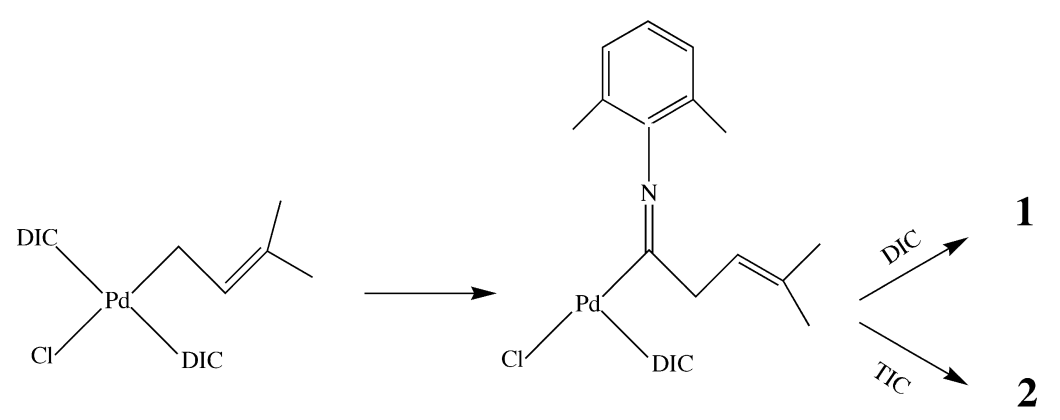

A

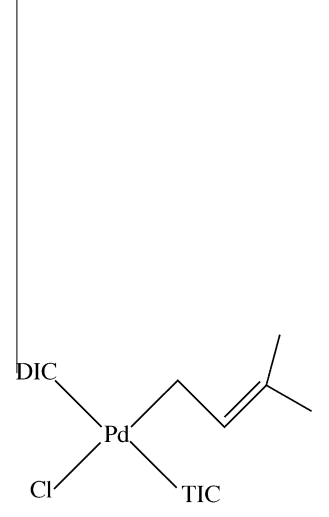

B<smiles>CC(C)=CC[Al](Cl)(Cl)Cl</smiles>

C

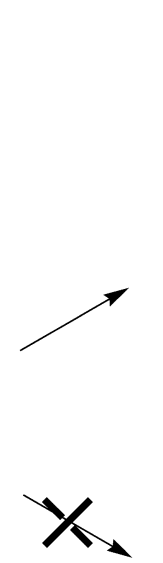<smiles>CC(C)=CCC(CCl)=Nc1c(C)cccc1C</smiles><smiles>C=CC</smiles>

3<smiles>C#CC</smiles>

5<smiles>CC(C)=CCC(=NC(C)(C)C)[Te](Cl)Cl</smiles><smiles>C=CC</smiles>

5

6

Scheme 2.

ble products are the species $\mathbf{1}, \mathbf{2}$, and 3, namely only those with DIC inserted into the Pd-C bond.

This high selectivity attests the marked preference of allyl fragment to migrate on the aromatic isocyanide. Interestingly complex 2, which presents the correct stoichiometric ratio between DIC and TIC (2:1), amounts to the $50 \%$ of the mixture, whereas each species 1 and 3 represents 25\% of the total. This evidence needs a further elucidation. It is likely that immediately after the addition of DIC and TIC to the complex [ $\left.\mathrm{Pd}(\mathrm{DIC}) \mathrm{Cl}\left(\eta^{3}-\mathrm{C}_{3} \mathrm{H}_{3} \mathrm{Me}_{2}\right)\right]$ three different reactive intermediates are formed as a consequence of the introduction of an isocyanide molecule into the coordination sphere and the reduction of hapticity of the allyl fragment from $\eta^{3}$ to $\eta^{1}$ (Scheme 2), the possibility of the fast exchange between coordinated and free isocyanides being also taken into account. Apparently only the intermediates $\mathbf{A}$ and $\mathbf{B}$ evolve into the final products (respectively $\mathbf{1}$ or $\mathbf{2}$ and $\mathbf{2}$ or $\mathbf{3}$ ), since the allyl migration on the aromatic isocyanide is far more favoured than that on the alkyl isocyanide. At this point one equivalent of free TIC and one equivalent of free DIC remain available for occupying the fourth coordination site. According to the previously proved comparable coordinating capability, the statistical distribution between mixed species 2 and homoleptic species $\mathbf{1}$ and $\mathbf{3}$ will again be obtained.

In a second experiment we have added two equivalents of TIC to a solution of $\left[\operatorname{Pd}(\mathrm{DIC}) \mathrm{Cl}\left(\eta^{3}-\mathrm{C}_{3} \mathrm{H}_{3} \mathrm{Me}_{2}\right)\right]$ in $\mathrm{CDCl}_{3}$, with the purpose of verifying if an increased ratio between TIC and DIC is sufficient to induce partial insertion of the TIC into the Pd- $\eta^{1}$ allyl bond. Actually the resulting mixture contained some amounts of the species 5 and $\mathbf{6}$ (Fig. 3), but curiously no trace of 4.

As depicted in Scheme 2 the only pathway to complex $\mathbf{4}$ goes through the intermediate $\mathbf{B}$ and involves the subsequent preferen- 


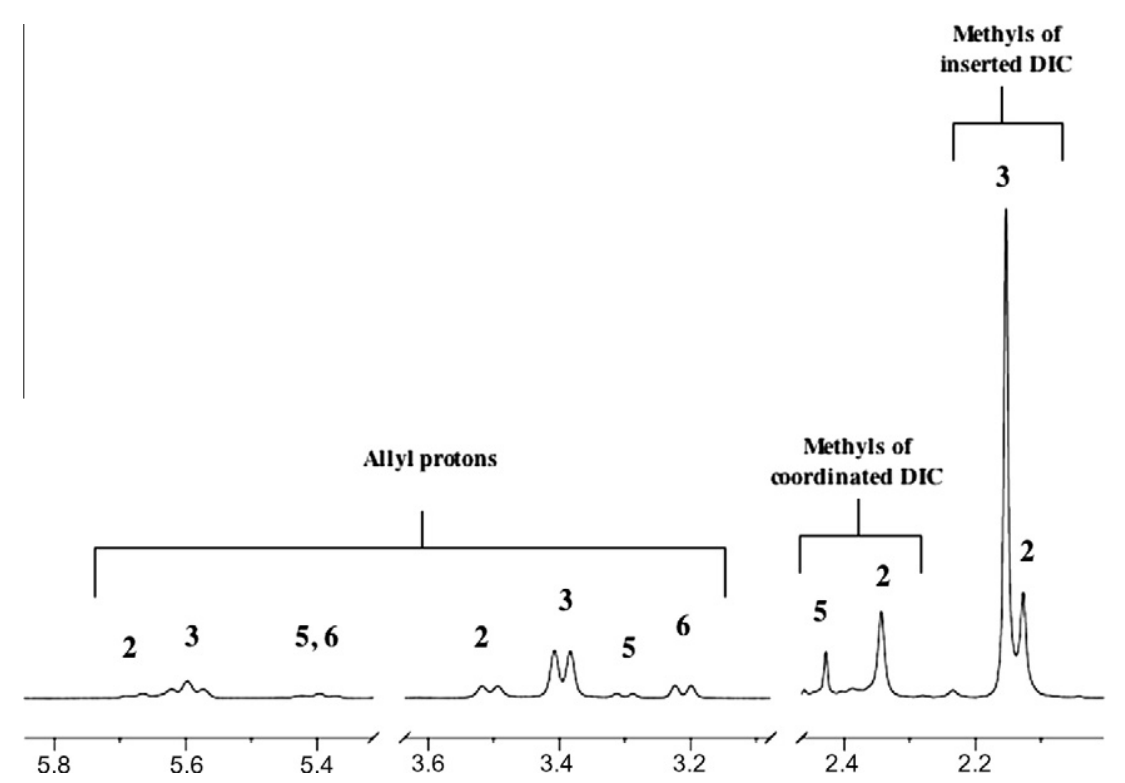

Fig. 3. Extract of ${ }^{1} \mathrm{H}$ NMR spectrum (in $\mathrm{CDCl}_{3}$ at $298 \mathrm{~K}$ ) related to the reaction of $\left[\mathrm{Pd}(\mathrm{DIC}) \mathrm{Cl}\left(\eta^{3}-\mathrm{C}_{3} \mathrm{H}_{3} \mathrm{Me}_{2}\right)\right]$ with 2 equiv. of TIC.

tial migration of the allyl fragment on the coordinated TIC and eventually the filling of the resulting vacant site by a molecule of DIC. The absence of species $\mathbf{4}$ in the final products excludes this possibility and indicates once again the absolute preference of allyl fragment to migrate on DIC over TIC. On the other hand, the observable species $\mathbf{5}$ which theoretically might also be obtained from the intermediate $\mathbf{B}$ indeed derives from the alternative precursor C. This intermediate, for which the insertion of TIC is obviously the only option, gives rise also to the final complex 6 which appears in the final spectrum (Scheme 2). Therefore in this second experiment the favourable ratio TIC/DIC, in addition to the faster disappearance of the DIC for insertion, renders competitive the path involving intermediate $\mathbf{C}$, which was virtually negligible in the first experiment. Moreover, the low amount of DIC available is also the reason for the absence of species $\mathbf{1}$ among the products.

\section{Conclusion}

In this contribution we have demonstrated that the nature of the isocyanide scarcely affects its coordinative capability on palladium(II) but heavily influences the efficiency of the migratory insertion of the allyl fragment. These results are achieved on the basis of the mere analysis of the mixture of products obtained by the reaction of appropriate palladium substrates with variable amounts of two different isocyanides.

In previous works it was observed that the overall insertion rate increases with increasing electrophilicity and with reducing steric hindrance on the isocyanide carbon $[4,5,9,10]$. This tendency is confirmed in the present paper but in addition we have shown that pre-coordination of the isocyanide, a preliminary step of the process, is practically insensitive to its electronic and steric features. For this reason the effect of the nature of the isocyanide on the overall reaction rate can be wholly attributed to its influence on the migration step.

\section{Experimental}

1D and 2D NMR spectra were recorded using a Bruker DPX300 spectrometer. Chemical shifts (ppm) are given relative to TMS $\left({ }^{1} \mathrm{H}\right.$ NMR $)$.
Peaks are labelled as singlet (s), doublet (d), triplet (t), quartet $(\mathrm{q})$, multiplet $(\mathrm{m})$ and broad (br). The proton assignment was performed also by ${ }^{1} \mathrm{H}-2 \mathrm{D}$ COSY.

$\left[\mathrm{Pd}(\mu-\mathrm{Cl})\left(\eta^{3}-\mathrm{C}_{3} \mathrm{H}_{5}\right)\right]_{2}{ }^{10}, \quad\left[\mathrm{Pd}(\mathrm{DIC}) \mathrm{Cl}\left(\eta^{3}-\mathrm{C}_{3} \mathrm{H}_{3} \mathrm{Me}_{2}\right)\right]^{7}$, trans-[Pd(DIC) $\left.)_{2}\left(\mathrm{C}=\mathrm{N}\left(2,6-\mathrm{Me}_{2} \mathrm{C}_{6} \mathrm{H}_{3}\right) \mathrm{CH}_{2} \mathrm{CHCMe}_{2}\right) \mathrm{Cl}\right]^{7}$ (1) and trans- $\left[\mathrm{Pd}(\mathrm{TIC})_{2}\right.$ $\left.\left(\mathrm{C}=\mathrm{N}\left(\mathrm{CMe}_{3}\right) \mathrm{CH}_{2} \mathrm{CHCMe}_{2}\right) \mathrm{Cl}\right]^{7}(\mathbf{6})$, were synthesized according to previously reported procedures. The isocyanides tert-butyl isocyanide (TIC) and the 2,6-dimethylphenyl isocyanide (DIC) were purchased from Fluka and used without purification. All other chemicals and solvents were reagent grade and were used without further purification.

\subsection{Synthesis of $\left[\mathrm{Pd}(\mathrm{DIC})_{2}\left(\eta^{3}-\mathrm{C}_{3} \mathrm{H}_{5}\right)\right] \mathrm{ClO}_{4}$}

To $0.12 \mathrm{~g}(0.328 \mathrm{mmol})$ of $\left[\mathrm{Pd}(\mu-\mathrm{Cl})\left(\eta^{3}-\mathrm{C}_{3} \mathrm{H}_{5}\right)\right]_{2}$ in $15 \mathrm{~mL}$ of $\mathrm{CH}_{2} \mathrm{Cl}_{2}, 0.172 \mathrm{~g}(1.312 \mathrm{mmol})$ of DIC in $5 \mathrm{~mL}$ of the same chlorinated solvent was added. Addition of an excess of $\mathrm{NaClO}_{4} \cdot \mathrm{H}_{2} \mathrm{O}$ $(0.184 \mathrm{~g}, 1.312 \mathrm{mmol})$ dissolved in $6 \mathrm{~mL}$ of $\mathrm{CH}_{3} \mathrm{OH}$ to the stirred mixture yielded the precipitation of $\mathrm{NaCl}$. The reaction mixture was stirred for $30 \mathrm{~min}$ and then the solvent was removed under reduced pressure. The whitish solid was extracted with $20 \mathrm{~mL}$ of $\mathrm{CH}_{2} \mathrm{Cl}_{2}$, treated with activated charcoal and filtered off through Celite. Evaporation to small volume yielded the crude precipitate, which was recrystallized from $\mathrm{CH}_{2} \mathrm{Cl}_{2}, / \mathrm{Et}_{2} \mathrm{O}$ as a white solid and dried in vacuo. Yield $0.302 \mathrm{~g}(90 \%) .{ }^{1} \mathrm{H}$ NMR $\left(\mathrm{CDCl}_{3}, 298 \mathrm{~K}\right) \delta 2.51$ $\sigma, 12 \mathrm{H}$, DIC $\left.\mathrm{CH}_{3}\right), 3.77$ (d, $J=13.4 \mathrm{~Hz}, 2 \mathrm{H}$, allyl $\mathrm{H}_{\text {ant }}$ ), 5.03 (d, $J=7.3 \mathrm{~Hz}, 2 \mathrm{H}$, allyl $\left.\mathrm{H}_{\text {syn }}\right), 5.90\left(\mathrm{~m}, 1 \mathrm{H}\right.$, allyl $\left.\mathrm{H}_{\text {central }}\right), 7.19$ (d, $J$ $=7.7 \mathrm{~Hz}, 4 \mathrm{H}$, DIC $\left.\mathrm{H}_{\text {meta }}\right), 7.32\left(\mathrm{t}, J=7.7 \mathrm{~Hz}, 2 \mathrm{H}, \mathrm{H}_{\text {para }}\right) .{ }^{13} \mathrm{C}\left\{{ }^{1} \mathrm{H}\right\} \mathrm{NMR}$ $\left(\mathrm{CDCl}_{3}, T=298 \mathrm{~K}, \mathrm{ppm}\right): \delta 18.72\left(\mathrm{CH}_{3}\right.$, DIC $\left.\mathrm{CH}_{3}\right), 71.45\left(\mathrm{CH}_{2}\right.$, allyl $\left.\mathrm{C}_{\text {terminal }}\right), 122.98\left(\mathrm{CH}\right.$, allyl $\left.\mathrm{C}_{\text {central }}\right), 125.44(\mathrm{C}$, DIC C-N), 128.24 $\left(\mathrm{CH}\right.$, DIC C $\left.\mathrm{C}_{\text {meta }}\right), 130.61$ (CH, DIC $\left.\mathrm{C}_{\text {para }}\right), 135.87$ (C, DIC C $\left.{ }^{2}, \mathrm{C}_{\text {ortho }}\right)$, 145.26 (C, C-Pd). IR ( $\mathrm{KBr}$ pellet, $\left.\mathrm{cm}^{-1}\right) v=2179(\mathrm{CN}), 1094.5\left(\mathrm{ClO}_{4}\right)$.

Anal. Calc. for $\mathrm{C}_{21} \mathrm{H}_{23} \mathrm{ClN}_{2} \mathrm{O}_{4} \mathrm{Pd}$ : C, 49.52; $\mathrm{H}, 4.55 ; \mathrm{N}, 5.50$. Found C, 49.64; H, 4.56; N, 5.39\%.

\subsection{Synthesis of $\left[\mathrm{Pd}(\mathrm{TIC})_{2}\left(\eta^{3}-\mathrm{C}_{3} \mathrm{H}_{5}\right)\right] C \mathrm{ClO}_{4}$}

The synthesis of the title complex is analogous to that of $\left[\mathrm{Pd}(\mathrm{DIC})_{2}\left(\eta^{3}-\mathrm{C}_{3} \mathrm{H}_{5}\right)\right] \mathrm{ClO}_{4}$, starting from $0.12 \mathrm{~g}(0.328 \mathrm{mmol})$ of $\left[\mathrm{Pd}(\mu-\mathrm{Cl})\left(\eta^{3}-\mathrm{C}_{3} \mathrm{H}_{5}\right)\right]_{2}, 0.109 \mathrm{~g}(1.312 \mathrm{mmol})$ of TIC and an excess of $\mathrm{NaClO}_{4} \mathrm{H}_{2} \mathrm{O}(0.184 \mathrm{~g}, 1.312 \mathrm{mmol})$. Yield $0.239 \mathrm{~g}(88 \%) .{ }^{1} \mathrm{H}$ NMR 
$\left.\left(\mathrm{CDCl}_{3}, 298 \mathrm{~K}\right) \delta 1.62 \sigma, 18 \mathrm{H}, \mathrm{C}\left(\mathrm{CH}_{3}\right)_{3}\right), 3.36(\mathrm{~d}, J=13.4 \mathrm{~Hz}, 2 \mathrm{H}$, allyl $\left.\mathrm{H}_{\text {anti }}\right), 4.78\left(\mathrm{~d}, J=7.3 \mathrm{~Hz}, 2 \mathrm{H}\right.$, allyl $\left.\mathrm{H}_{\text {syn }}\right), 5.64\left(\mathrm{~m}, 1 \mathrm{H}\right.$, allyl $\left.\mathrm{H}_{\text {central }}\right)$. ${ }^{13} \mathrm{C}\left\{{ }^{1} \mathrm{H}\right\}$ NMR $\left(\mathrm{CDCl}_{3}, T=298 \mathrm{~K}, \mathrm{ppm}\right): \delta 29.93\left(\mathrm{CH}_{3}, \mathrm{C}\left(\mathrm{CH}_{3}\right)_{3}\right)$, $59.15\left(\mathrm{C}, \mathrm{C}\left(\mathrm{CH}_{3}\right)_{3}\right), 70.03\left(\mathrm{CH}_{2}\right.$, allyl $\left.\mathrm{C}_{\text {terminal }}\right), 122.26\left(\mathrm{CH}\right.$, allyl $\mathrm{C}_{\text {cen- }}$ tral), 131.14 (C, C-Pd). IR ( $\mathrm{KBr}$ pellet, $\mathrm{cm}^{-1}$ ) v $=2211$ (CN), 1093.0 $\left(\mathrm{ClO}_{4}\right)$.

Anal. Calc. for $\mathrm{C}_{13} \mathrm{H}_{23} \mathrm{ClN}_{2} \mathrm{O}_{4} \mathrm{Pd}$ : C, 37.79; $\mathrm{H}, 5.61 ; \mathrm{N}, 6.78$. Found C, $37.94 ; \mathrm{H}, 5.64 ; \mathrm{N}, 6.65 \%$.

4.3. Synthesis of the mixture of $\left[\mathrm{Pd}(\mathrm{TIC})(\mathrm{DIC})\left(\eta^{3}-\mathrm{C}_{3} \mathrm{H}_{5}\right)\right] \mathrm{ClO}_{4}(50 \%)$, $\left[\mathrm{Pd}(\mathrm{DIC})_{2}\left(\eta^{3}-\mathrm{C}_{3} \mathrm{H}_{5}\right)\right] \mathrm{ClO}_{4}(25 \%)$ and $\left[\mathrm{Pd}(\mathrm{TIC})_{2}\left(\eta^{3}-\mathrm{C}_{3} \mathrm{H}_{5}\right)\right] \mathrm{ClO}_{4}(25 \%)$

This statistical mixture is obtained by the same method used for the two previous complexes, starting from $0.12 \mathrm{~g}(0.328 \mathrm{mmol})$ of $\left[\mathrm{Pd}(\mu-\mathrm{Cl})\left(\eta^{3}-\mathrm{C}_{3} \mathrm{H}_{5}\right)\right]_{2}, 0.086 \mathrm{~g}(0.661 \mathrm{mmol})$ of DIC and $0.055 \mathrm{~g}$ ( $0.661 \mathrm{mmol})$ of TIC. Yield $0.282 \mathrm{~g}(93 \%)$.

${ }^{1} \mathrm{H}$ NMR $\left(\mathrm{CDCl}_{3}, 253 \mathrm{~K}\right)$ of mixed species $\left[\mathrm{Pd}(\mathrm{TIC})(\mathrm{DIC})\left(\eta^{3}-\right.\right.$ $\left.\left.\mathrm{C}_{3} \mathrm{H}_{5}\right)\right] \mathrm{ClO}_{4:} \delta 1.63 \sigma, 9 \mathrm{H}$, TIC C( $\left.\left.\left(\mathrm{CH}_{3}\right)_{3}\right), 2.48 \sigma, 6 \mathrm{H}, \mathrm{DIC} \mathrm{CH}_{3}\right), 3.49$ $\left(\mathrm{d}, J=13.4 \mathrm{~Hz}, 1 \mathrm{H}\right.$, allyl $\left.\mathrm{H}_{\text {anti }}\right), 3.53\left(\mathrm{~d}, J=13.4 \mathrm{~Hz}, 1 \mathrm{H}\right.$, allyl $\left.\mathrm{H}_{a n t i}\right)$, $4.90\left(\mathrm{~d}, J=7.3 \mathrm{~Hz}, 1 \mathrm{H}\right.$, allyl $\left.\mathrm{H}_{s y n}\right), 4.96\left(\mathrm{~d}, J=7.3 \mathrm{~Hz}, 1 \mathrm{H}\right.$, allyl $\left.\mathrm{H}_{s y n}\right)$, $5.76\left(\mathrm{~m}, 1 \mathrm{H}\right.$, allyl $\left.\mathrm{H}_{\text {central }}\right), 7.20\left(\mathrm{~d}, J=7.7 \mathrm{~Hz}, 2 \mathrm{H}\right.$, DIC $\left.\mathrm{H}_{\text {meta }}\right), 7.34(\mathrm{t}$, $\left.J=7.7 \mathrm{~Hz}, 1 \mathrm{H}, \mathrm{H}_{\text {para }}\right)$.

\subsection{Study of the products of insertion of TIC and DIC to complex} $\left[\mathrm{Pd}(\mathrm{DIC}) \mathrm{Cl}\left(\eta^{3}-\mathrm{C}_{3} \mathrm{H}_{3} \mathrm{Me}_{2}\right)\right]$

These studies were carried out by ${ }^{1} \mathrm{H}$ NMR technique. In the first experiment we added in succession one equivalent of DIC $(0.003 \mathrm{~g})$ and one equivalent of TIC $(2.7 \mu \mathrm{L})$ to $0.8 \mathrm{~cm}^{3}$ of a solution $(3 \times$ $10^{-2} \mathrm{~mol} \mathrm{dm}{ }^{-3}$ ) of the title complex in $\mathrm{CDCl}_{3}$. The final spectrum, recorded after $10 \mathrm{~min}$, remained unchanged with time.

In the second experiment we added with a micropipette two equivalents $(5.4 \mu \mathrm{L})$ of TIC to $0.8 \mathrm{~cm}^{3}$ of a solution $\left(3 \times 10^{-2}\right.$ mol dm${ }^{-3}$ ) of the title complex in $\mathrm{CDCl}_{3}$. The spectrum of the reaction is recorded after $10 \mathrm{~min}$, and it did not change with time.

\section{References}

[1] (a) J. Tsuji, Palladium Reagents and Catalysts, Wiley, Chichester, 1996;

(b) G.W. Parshall, S.D. Ittel, Homogeneous Catalysis, Wiley, New York, 1992;

(c) R.H. Crabtree, The Organometallic Chemistry of the Transition Metals, Wiley, New York, 2005.
[2] (a) J. Dupont, M. Pfeffer, J.C. Daran, Y. Jeannin, Organometallics 6 (1987) 899; (b) A. Zografidis, K. Polborn, W.Z. Beck, B.A. Markies, G. van Koten, Naturforsh., B: Chem. Sci. 49 (1994) 1494;

(c) A. Yamamoto, Bull. Chem. Soc. Jpn. 68 (1995) 433;

(d) J. Vicente, J.A. Abad, K.F. Shaw, J. Gil-Rubio, M.C. Ramirez de Arellano, P.G. Jones, Organometallics 16 (1997) 4557;

(e) A. Böhm, K. Polborn, K. Sunkel, W.Z. Beck, Naturforsh., B: Chem. Sci. 53 (1994) 448;

(f) Y.S. Lin, A. Yamamoto, Organometallics 17 (1998) 3466;

(g) J. Vicente, I. Saura Llamas, J. Turpin, M.C. Ramirez de Arellano, P.G. Jones, Organometallics 18 (1999) 2683;

(h) A. Yamamoto, J. Chem. Soc., Dalton Trans. (1999) 1027;

(i) C.G. Saluste, R.J. Whitby, M. Furber, Angew. Chem., Int. Ed. 39 (2000) 4156; (j) J. Vicente, J.A. Abad, A.D. Frankland, J. Lopez-Serrano, M.C. Ramirez de Arellano, P.G. Jones, Organometallics 21 (2002) 272;

(k) K. Onitsuka, M. Yamamoto, S. Suzuki, S. Takahashi, Organometallics 21 (2002) 581;

(1) J. Vicente, J.A. Abad, E. Martinez-Viviente, P.G. Jones, Organometallics 21 (2002) 4454;

(m) D.P. Curran, W. Du, Org. Lett. 4 (2002) 3215;

(n) Y.J. Kim, X.H. Chang, J.T. Han, M.S. Lim, S.W. Lee, Dalton Trans. (2004) 3699;

(o) J. Albert, L. D’Andrea, J. Granell, J. Zafrilla, M. Font-Badia, X.J. Solans, J. Organomet. Chem. 692 (2007) 4895;

(p) M. Bortoluzzi, G. Paolucci, B. Pitteri, A. Vavasori, V. Bertolasi, Organometallics 28 (2009) 3247.

[3] Y. Kayaki, I. Shimizu, A. Yamamoto, Bull. Chem. Soc. Jpn. 70 (1997) 917.

[4] (a) J.G.P. Delis, K. Vrieze, P.G. Aubel, P.W.N.M. van Leeuwen, N. Veldman, A.L. Spek, F.J.R. van Neer, Organometallics 16 (1997) 2948;

(b) J.G.P. Delis, K. Vrieze, P.G. Aubel, P.W.N.M. van Leeuwen, N. Veldman, A.L. Spek, J. Chem. Soc., Chem. Commun. (1995) 2333;

(c) Sometimes isocyanide reacts to afford a product in which it is not inserted but simply coordinated. See Ref. [2(d)] J. Vicente, M.T. Chicote, A.J. MartínezMartínez, P.G. Jones, D. Bautista, Organometallics 27 (2008) 3254.

[5] L. Canovese, F. Visentin, C. Santo, C. Levi, A. Dolmella, Organometallics 26 (2007) 5590.

[6] (a) K. Onitsuka, H. Ogawa, T. Joh, S. Takahashi, Y. Yamamoto, H. Yamazaki, J. Chem. Soc., Dalton Trans. (1991) 1531;

(b) Y. Yamamoto, T. Tanase, T. Yanai, T. Asano, K. Kobayashi, J. Organomet. Chem. 456 (1993) 287:

(c) K. Onitsuka, T. Joh, S. Takahashi, J. Organomet. Chem. 464 (1994) 247;

(d) J.F. van Baar, J.M. Klerks, P. Overbosch, D. Stufkens, K. Vrieze, J. Organomet. Chem. 112 (1976) 95;

(e) T. Tanase, T. Ohizumi, K. Kobayashi, Y. Yamamoto, Organometallics 15 (1996) 3404;

(f) Y. Ito, E. Ihara, M. Murakami, M. Shiro, J. Am. Chem. Soc. 112 (1990) 6446; (g) G.R. Owen, R. Vilar, A.J.P. White, D.J. Williams, Organometallics 21 (2002) 4799.

[7] L. Canovese, F. Visentin, C. Santo, C. Levi, Organometallics 28 (2009) 6762.

[8] B. Crociani, F. Di Bianca, A. Giovenco, T. Boschi, Inorg. Chim. Acta 127 (1987) 169.

[9] B. Crociani, Reactions of Coordinated Ligands, vol. 1, Plenum, New York, 1982.

[10] F.R. Hartley, S.R. Jones, J. Organomet. Chem. 66 (1974) 465. 